\title{
VHL status regulates transforming growth factor- $\beta$ signaling pathways in renal cell carcinoma
}

\author{
Pramod Mallikarjuna ${ }^{1, *}$, Raviprakash T. Sitaram ${ }^{1,2, *}$, Maréne Landström ${ }^{1, * *}$ and \\ Börje Ljungberg ${ }^{2, * *}$ \\ ${ }^{1}$ Department of Medical Biosciences, Pathology, Umeå University, Umeå SE-90187, Sweden \\ ${ }^{2}$ Department of Surgical and Perioperative Sciences, Urology and Andrology, Umeå University, Umeå SE-90187, Sweden \\ *These authors have contributed equally to this work as first author \\ *** These authors have contributed equally to this work as last author
}

Correspondence to: Raviprakash T. Sitaram, email: RAVIPRAKASH@UMU.SE

Keywords: CCRCC; non-CCRCC; ALK5; PVHL; TGF- $\beta$ signaling

Received: November 16, $2017 \quad$ Accepted: February 27, $2018 \quad$ Published: March 27, 2018

Copyright: Mallikarjuna et al. This is an open-access article distributed under the terms of the Creative Commons Attribution License 3.0 (CC BY 3.0), which permits unrestricted use, distribution, and reproduction in any medium, provided the original author and source are credited.

\section{ABSTRACT}

To evaluate the role of $\mathrm{pVHL}$ in the regulation of TGF- $\beta$ signaling pathways in clear cell renal cell carcinoma (CCRCC) as well as in non-ccRCC; the expression of PVHL, and the TGF- $\beta$ pathway components and their association with clinicopathological parameters and patient's survival were explored. Tissue samples from 143 cCRCC and 58 non-cCRCC patients were examined by immunoblot. cCRCC cell lines were utilized for mechanistic in-vitro studies. Expression levels of pVHL were significantly lower in cCRCC compared with non-ccRCC. Non-cCRCC and CCRCC pVHL-High expressed similar levels of pVHL. Expression of the TGF- $\beta$ type I receptor (ALK5) and intra-cellular domain were significantly higher in cCRCC compared with non-ccRCC. In non-ccRCC, expressions of ALK5-FL, ALK5-ICD, PSMAD2/3, and PAI-1 had no association with clinicopathological parameters and survival. In cCRCC pVHL-Low, ALK5-FL, ALK5ICD, pSMAD2/3, and PAI-1 were significantly related with tumor stage, size, and survival. In ccRCC pVHL-High, the expression of PAI-1 was associated with stage and survival. In-vitro studies revealed that PVHL interacted with ALK5 to downregulate its expression through K48-linked poly-ubiquitination and proteasomal degradation, thus negatively controlling TGF- $\beta$ induced cancer cell invasiveness. The pVHL status controls the ALK5 and can thereby regulate the TGF- $\beta$ pathway, aggressiveness of tumors, and survival of the CCRCC and non-cCRCC patients.

\section{INTRODUCTION}

Renal cell carcinoma (RCC) is a heterogeneous tumor caused by alterations in different genes. Based on various histological appearance and cytogenetic abnormality, RCC is classified into several subtypes [1, 2]. Main RCC types are clear cell RCC (ccRCC), papillary (pRCC), and chromophobe RCC (chRCC) [3]. Clear cell type is the most frequent RCC, accounting for $70-80 \%$ of RCCs, having a five years overall survival rate of about $55-60 \%$. Papillary type represents $15-20 \%$ of RCC with five years survival rate about $70-90 \%$, and chromophobe type counts for $6-11 \%$ of RCC with a five years survival rate of $80-95 \%$. Both pRCC and chRCC revealed the hypovascular feature unlike ccRCC [4]. The differences in prognosis and tumor behavior of the different RCC types are due to the involvement of various genes and signaling pathways [5]. The pRCC is associated with germline mutations of MET proto-oncogene, and these mutations activate MET signaling to promote tumor and cell motility [6]. Recurrent genetic alterations found in chRCC are the loss of heterozygosity (LOH) at chromosomes 1, 2, 6, 10, 13, 17 and 21, and are associated with Brit Hogg Dube syndrome [6]. 
In ccRCC, common genetic aberrations are $\mathrm{LOH}$, hypermethylation, or mutation or deletions in the $3 p$ chromosome region [7]. Frequent aberrations of chromosome $3 \mathrm{p}$ region cause inactivation of von Hippel-Lindau (VHL) gene in ccRCC. In contrast, VHL is unaltered in pRCC and chRCC. The VHL protein (pVHL), encoded by the tumor suppressor gene $V H L$, serves as an adaptor protein like E3-ubiquitin ligase complex and
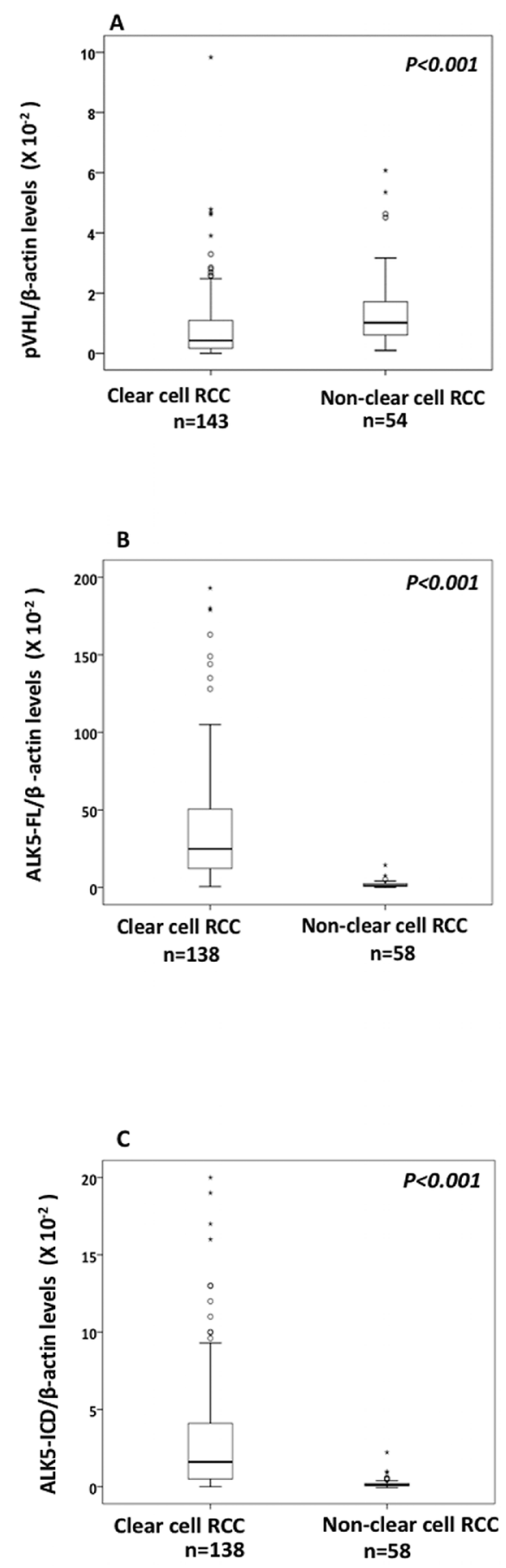

targets HIF subunits for degradation by ubiquitination [8, 9]. In cases with inactive or absent pVHL, stabilization of Hypoxic $\alpha$ units (HIF-1 and HIF-2) occurs, leading to tumor forming and tumor promoting properties of ccRCC $[10,11]$. The pVHL mediates both K48- and K63linked poly-ubiquitination, which is involved in protein degradation, protein trafficking, and post-translational modification respectively [12]. Besides interaction with
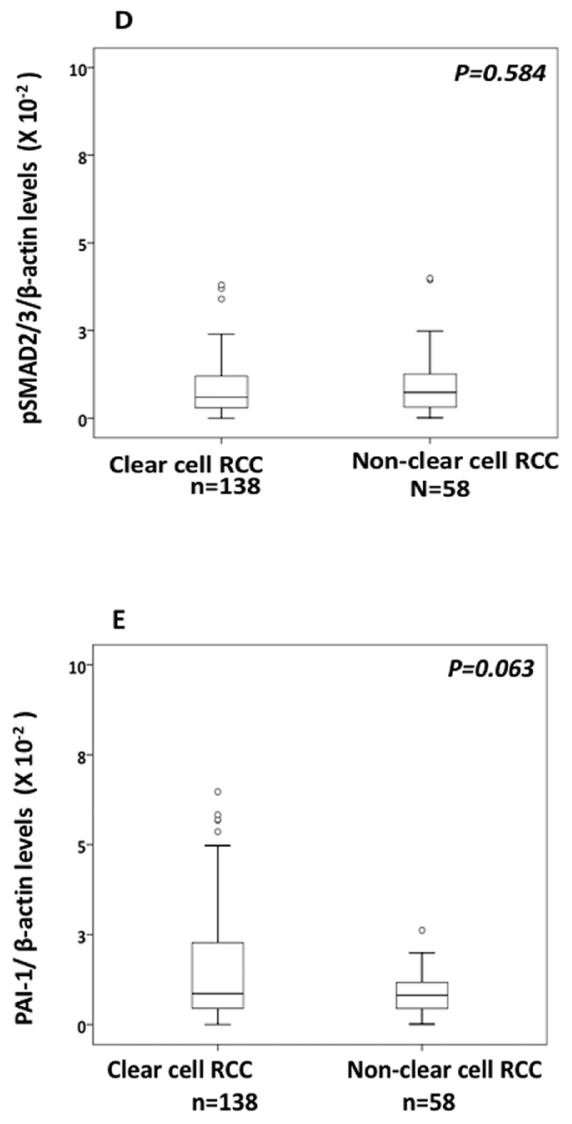

Figure 1: Box plot representation of expression of (A) pVHL, (B) ALK5-FL, (C) ALK5-ICD, (D) pSMAD2/3, (E) PAI-1 protein in the non-ccRCC compared with ccRCCs. 
Table 1: Relation of pVHL levels to categorized clinicopathological parameters in ccRCC and non-ccRCC

\begin{tabular}{|c|c|c|c|c|c|c|c|c|c|c|c|c|}
\hline \multirow[b]{2}{*}{ Parameter } & \multicolumn{3}{|c|}{ ccRCC pVHL } & \multicolumn{3}{|c|}{ ccRCC pVHL-Low } & \multicolumn{3}{|c|}{ ccRCC pVHL-High } & \multicolumn{3}{|c|}{ Non-ccRCC pVHL } \\
\hline & $\mathbf{n}^{\mathbf{a}}$ & $\begin{array}{l}\text { Mean } \\
\text { Rank }\end{array}$ & $\begin{array}{c}P \text { - } \\
\text { Value }^{\text {b }}\end{array}$ & $\mathbf{n}^{\mathrm{a}}$ & $\begin{array}{l}\text { Mean } \\
\text { Rank }\end{array}$ & $\begin{array}{c}P \text { - } \\
\text { Value }^{\text {b }}\end{array}$ & $\mathbf{n}^{\mathrm{a}}$ & $\begin{array}{l}\text { Mean } \\
\text { Rank }\end{array}$ & $\begin{array}{c}P \text { - } \\
\text { Value }^{\text {b }}\end{array}$ & $\mathbf{n}^{\mathbf{a}}$ & $\begin{array}{l}\text { Mean } \\
\text { Rank }\end{array}$ & $\begin{array}{c}P \text { - } \\
\text { Value }^{\text {b }}\end{array}$ \\
\hline \multicolumn{13}{|l|}{ Grade } \\
\hline \multirow[t]{2}{*}{$\mathrm{I}(\mathrm{I}+\mathrm{II})$} & 72 & 74.25 & & 36 & 36.64 & & 36 & 40.86 & & 32 & 29.23 & \\
\hline & & & 0.513 & & & 0.791 & & & 0.077 & & & 0.328 \\
\hline II (III+IV) & 71 & 69.72 & & 35 & 35.34 & & 36 & 32.14 & & 22 & 24.98 & \\
\hline \multicolumn{13}{|l|}{ TNM Stage } \\
\hline \multirow[t]{2}{*}{ Early Stage (I+II) } & 79 & 70.03 & & 40 & 33.48 & & 39 & 36.51 & & 38 & 29.86 & \\
\hline & & & 0.527 & & & 0.242 & & & 0.995 & & & 0.090 \\
\hline $\begin{array}{l}\text { Advanced Stage } \\
\text { (III+IV) }\end{array}$ & 64 & 74.44 & & 31 & 39.26 & & 33 & 36.48 & & 16 & 21.91 & \\
\hline \multicolumn{13}{|l|}{ Tumor size (mm) } \\
\hline \multirow[t]{2}{*}{$<70$} & 72 & 67.57 & & 41 & 35.07 & & 31 & 39.55 & & 33 & 28.89 & \\
\hline & & & 0.198 & & & 0.658 & & & 0.283 & & & 0.414 \\
\hline$>70$ & 71 & 76.49 & & 30 & 37.27 & & 41 & 34.20 & & 21 & 25.31 & \\
\hline
\end{tabular}

HIF- $\alpha$, pVHL also associates with various proteins and mediates different biological processes [8]. In RCC, pVHL might negatively modulate transforming growth factor- $\beta$ (TGF- $\beta$ ) pathways $[13,14]$.

TGF- $\beta$ is a key regulatory cytokine controlling vital processes, such as immune responses, differentiation of cells, and tissue homeostasis. Initially, TGF- $\beta$ acts as a tumor suppressor, but in the later stages of the tumor, TGF- $\beta$ acts as a tumor promoter [15]. TGF- $\beta$ signals through canonical and non-canonical modes [16-18]. In canonical signaling, TGF- $\beta$ ligand binds to a constitutively active TGF- $\beta$ type II receptor (T $\beta$ RII); TBRII thereafter recruits and activates TGF- $\beta$ type I receptor (TBRI or ALK5 or ALK5-Full Length; ALK5FL) by phosphorylation in its serine/glycine-rich sequence called the GS domain. Activated T $\beta R I$ then activates SMAD2 and SMAD3, which translocates to the nucleus together with SMAD4 to turn on target genes in a contextual manner [15]. In non-canonical signaling, T $\beta$ RI is cleaved by proteolytic enzymes to liberate an intracellular domain (T $\beta$ RI-ICD or ALK5-ICD) [19, 20]. Though the exact tumor promoting mechanism of ALK5-ICD needs to be further elucidated, studies have established the ability of ALK5-ICD to promote cancer and its localization in the nucleus of tumor cells [1820]. The TGF- $\beta$ signaling imparts its impact as a tumor promoter by activating tumor-promoting genes in the nucleus [20]. One of the well-known targets of TGF- $\beta$ signaling is Plasminogen activator inhibitor type-1 (PAI-1) [21]. Increased expression of PAI-1 is seen in various forms of cancer [22-24], and it is also associated with poor prognosis in ccRCC $[25,26]$. Recently, we investigated canonical and non-canonical components of TGF- $\beta$ signaling pathway and demonstrated the poor survival imparted by TGF- $\beta$ signaling and PAI- 1 , in patients with ccRCC [25].

In the present study, we investigate the role of TGF- $\beta$ signaling pathways in non-ccRCC, having normal functioning $\mathrm{pVHL}$. We also investigated the regulation of TGF- $\beta$ signaling in ccRCC, based on the levels of $\mathrm{pVHL}$ expression. Further, to elucidate the mode of action of TGF- $\beta$ and it's abilities to induce tumor aggressiveness depending on the levels of pVHL expression, we utilized two ccRCC cell lines A498 ( $\left.\mathrm{VHL}^{-/}\right)$and ACHN $\left(\mathrm{VHL}^{+/+}\right)$ for in-vitro studies.

\section{RESULTS}

\section{Expression patterns of $\mathrm{pVHL}$ in ccRCC and non- ccRCC}

The pVHL levels were significantly lower in ccRCC $(\mathrm{n}=143)$ than its corresponding kidney cortex $(\mathrm{n}=35)$ $(P=0.012)$, as well as non-ccRCC $(\mathrm{n}=54) \quad(P<0.001$, Figure 1A). For non-ccRCC $(\mathrm{n}=54)$ there was no difference in pVHL levels $(P=0.663)$ when compared with corresponding kidney cortex $(n=20)$.

Based on the median value of $\mathrm{pVHL}$ expression, the ccRCCs $(n=143)$ were divided into two subgroups: ccRCC pVHL-Low $(n=71)$ and ccRCC pVHL-High $(n=72)$. 
Table 2: Relation of ALK5-FL, ALK5-ICD, pSMAD2/3 and PAI-1 protein levels to categorized clinicopathological parameters in non-ccRCC

\begin{tabular}{|c|c|c|c|c|c|c|c|c|c|c|c|c|}
\hline \multirow[b]{2}{*}{ Parameter } & \multicolumn{3}{|c|}{ ALK5-FL } & \multicolumn{3}{|c|}{ ALK5-ICD } & \multicolumn{3}{|c|}{ pSMAD2/3 } & \multicolumn{3}{|c|}{ PAI-1 } \\
\hline & $\mathbf{n}^{\mathbf{a}}$ & $\begin{array}{l}\text { Mean } \\
\text { Rank }\end{array}$ & $P$-Value ${ }^{\mathrm{b}}$ & $\mathbf{n}^{\mathrm{a}}$ & $\begin{array}{l}\text { Mean } \\
\text { Rank }\end{array}$ & $P$-Value ${ }^{\mathrm{b}}$ & $\mathbf{n}^{\mathrm{a}}$ & $\begin{array}{l}\text { Mean } \\
\text { Rank }\end{array}$ & $\begin{array}{c}P \text { - } \\
\text { Value }^{\mathrm{b}}\end{array}$ & $\mathbf{n}^{\mathbf{a}}$ & $\begin{array}{l}\text { Mean } \\
\text { Rank }\end{array}$ & $P$-Value ${ }^{b}$ \\
\hline \multicolumn{13}{|l|}{ Grade } \\
\hline \multirow[t]{2}{*}{$\mathrm{I}(\mathrm{I}+\mathrm{II})$} & 33 & 28.58 & & 33 & 32.56 & & 33 & 27.82 & & 33 & 30.82 & \\
\hline & & & 0.632 & & & 0.113 & & & 0.384 & & & 0.495 \\
\hline II (III+IV) & 25 & 30.72 & & 25 & 25.46 & & 25 & 31.43 & & 25 & 27.76 & \\
\hline \multicolumn{13}{|l|}{ TNM Stage } \\
\hline \multirow[t]{2}{*}{ Early Stage (I+II) } & 40 & 28.38 & & 40 & 32.16 & & 40 & 27.58 & & 40 & 29.88 & \\
\hline & & & 0.449 & & & 0.073 & & & 0.196 & & & 0.801 \\
\hline $\begin{array}{l}\text { Advanced Stage } \\
(\mathrm{III}+\mathrm{IV})\end{array}$ & 18 & 32 & & 18 & 23.58 & & 18 & 33.78 & & 18 & 28.67 & \\
\hline \multicolumn{13}{|l|}{ Tumor size (mm) } \\
\hline \multirow[t]{2}{*}{$<70$} & 35 & 28.74 & & 35 & 29.21 & & 35 & 28.23 & & 35 & 30 & \\
\hline & & & 0.674 & & & 0.874 & & & 0.479 & & & 0.781 \\
\hline$>70$ & 23 & 30.65 & & 23 & 29.93 & & 23 & 31.43 & & 23 & 28.74 & \\
\hline
\end{tabular}

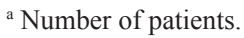

${ }^{\mathrm{b}}$ Groups were compared using Mann-Whitney U test (significant at $P<0.05$ ).

Table 3: Relation of ALK5-FL, ALK5-ICD, pSMAD2/3 and PAI-1 protein levels to categorized clinicopathological parameters in ccRCC VHL-Low

\begin{tabular}{|c|c|c|c|c|c|c|c|c|c|c|c|c|}
\hline \multirow[b]{2}{*}{ Parameter } & \multicolumn{3}{|c|}{ ALK5-FL } & \multicolumn{3}{|c|}{ ALK5-ICD } & \multicolumn{3}{|c|}{ pSMAD2/3 } & \multicolumn{3}{|c|}{ PAI-1 } \\
\hline & $\mathbf{n}^{\mathrm{a}}$ & $\begin{array}{l}\text { Mean } \\
\text { Rank }\end{array}$ & $P$-Value ${ }^{\text {b }}$ & $\mathbf{n}^{\mathrm{a}}$ & $\begin{array}{l}\text { Mean } \\
\text { Rank }\end{array}$ & $P$-Value ${ }^{\text {b }}$ & $\mathbf{n}^{\mathbf{a}}$ & $\begin{array}{l}\text { Mean } \\
\text { Rank }\end{array}$ & $P$-Value ${ }^{b}$ & $\mathbf{n}^{\mathrm{a}}$ & $\begin{array}{l}\text { Mean } \\
\text { Rank }\end{array}$ & $P$-Value \\
\hline \multicolumn{13}{|l|}{ Grade } \\
\hline \multirow[t]{2}{*}{$\mathrm{I}(\mathrm{I}+\mathrm{II})$} & 34 & 30.85 & & 34 & 30.49 & & 34 & 30.03 & & 34 & 28 & \\
\hline & & & 0.128 & & & 0.093 & & & 0.061 & & & 0.007 \\
\hline II (III+IV) & 34 & 38.15 & & 34 & 38.51 & & 34 & 38.97 & & 34 & 41 & \\
\hline \multicolumn{13}{|l|}{ TNM Stage } \\
\hline \multirow[t]{2}{*}{ Early Stage (I+II) } & 38 & 28.50 & & 38 & 29.53 & & 38 & 26.70 & & 38 & 26.49 & \\
\hline & & & 0.005 & & & 0.019 & & & 0.000 & & & 0.000 \\
\hline $\begin{array}{l}\text { Advanced Stage } \\
\text { (III+IV) }\end{array}$ & 30 & 42.10 & & 30 & 40.80 & & 30 & 44.38 & & 30 & 44.65 & \\
\hline \multicolumn{13}{|l|}{ Tumor size (mm) } \\
\hline \multirow[t]{2}{*}{$<70$} & 39 & 27 & & 39 & 29.05 & & 39 & 28.12 & & 39 & 27.33 & \\
\hline & & & 0.000 & & & 0.008 & & & 0.002 & & & 0.001 \\
\hline$>70$ & 29 & 44.59 & & 29 & 41.83 & & 29 & 43.09 & & 29 & 44.14 & \\
\hline
\end{tabular}

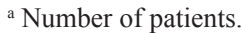

${ }^{\mathrm{b}}$ Groups were compared using Mann-Whitney $\mathrm{U}$ test (significant at $P<0.05$ ).

There were similar $\mathrm{pVHL}$ levels $(P=0.375)$ expressed in ccRCC pVHL-High $(\mathrm{n}=72)$ and non-ccRCC $(\mathrm{n}=54)$, while ccRCC pVHL-Low had significantly lower pVHL levels than non-ccRCC $(\mathrm{n}=71)(P<0.001)$. Expression levels of $\mathrm{pVHL}$ showed no association with clinicopathological parameters either in ccRCC irrespective of pVHL levels, or in non-ccRCC (Table 1) (Supplementary Figure 1A and Supplementary Figure 1B). 


\section{Expression pattern of ALK5-FL, ALK5-ICD, pSMAD2/3 and PAI-1 protein levels in ccRCC and non-ccRCC}

The protein expression of ALK5-FL and ALK5-ICD were significantly higher $(P<0.001)$ in ccRCC compared with non-ccRCC (Figure 1B and 1C), while there was no difference in the expression levels of pSMAD2/3 $(P=0$. $584)$ and PAI-1 $(P=0.063)$ (Figure 1D and 1E).

\section{Expression of ALK5-FL, ALK5-ICD, pSMAD2/3, PAI-1 proteins and their relation with clinicopathological parameters}

Protein levels of ALK5-FL, ALK5-ICD, pSMAD2/3, and PAI-1 in non-ccRCC did not associate with any of the clinicopathological parameters (Table 2).

In ccRCC pVHL-Low, the expression of ALK5-FL, ALK5-ICD, and pSMAD2/3 were significantly associated with the tumor stage and tumor diameter. However, PAI-1 was not only associated with the tumor stage and diameter but also with the tumor grade (Table 3 ). In ccRCC pVHLHigh, none of the TGF- $\beta$ signaling components were associated with clinicopathological parameters except ALK5-ICD, which associated with the tumor stage, and PAI-1 correlated with the tumor grade and stage (Table 4).

\section{Protein levels of pVHL, ALK5-FL, ALK5-ICD, pSMAD2/3, and PAI-1 and their relation with cancer-specific survival}

Expression of pVHL did not associate with cancerspecific survival in patients with ccRCC or in patients with non-ccRCC. The expression levels of ALK5-FL, ALK5-ICD, pSMAD2/3 and PAI-1 protein showed no association with survival in the non-ccRCC patients. In contrast, expression levels of ALK5-FL, ALK5-ICD, pSMAD2/3 and PAI- 1 proteins correlated with poor survival of ccRCC pVHL-Low patients. Notably, protein levels of ALK5-ICD and PAI-1 correlated with poor survival in ccRCC pVHL-High patients, while ALK5FL and pSMAD2/3 showed no correlation with survival (Figure 2A-2H).

\section{VHL status regulated downstream signaling targets of TGF- $\beta$ in ccRCC cell lines}

The A498 $\left(\mathrm{VHL}^{-/}\right)$and $\mathrm{ACHN}\left(\mathrm{VHL}^{+/+}\right)$cell lines were treated with TGF- $\beta$ at indicated time points. In A498 cells, TGF- $\beta$ treatment increased the protein level of PAI1 in a time dependent manner, but not in ACHN cells (Figure $3 \mathrm{~A}$ and $3 \mathrm{~B}, \mathrm{n}=3$ independent experiments).

In A498 cells, treatment with TGF- $\beta$ induced the expression of PAI-1 protein level, but the introduction of VHL along with TGF- $\beta$ treatment, reduced the expression PAI-1 protein level as well as the TGF- $\beta$ induced expression of endogenous ALK5 (Figure 3C, $\mathrm{n}=3$ independent experiments). In ACHN cells, cells treated with vehicle control (siRNA control) showed no expression of the PAI-1 protein, but knockdown of $V H L$ by siRNA showed expression of the PAI-1 protein. Further, knockdown of $V H L$ by siRNA and overexpression of ALK5, followed by TGF- $\beta$ treatment for 6 hours, enhanced the expression of PAI-1 protein level (Figure $3 \mathrm{D}, \mathrm{n}=3$ independent experiments).

Collectively, these results indicate that VHL status influences the efficiency of TGF- $\beta$ to induce its downstream targets in ccRCC cell lines.

\section{VHL suppressed the invasion of ccRCC cell lines induced by TGF- $\beta$}

In A498 cells, overexpression of $A L K 5-H A$ followed by treatment with TGF- $\beta$ increased the invasiveness of cells. However, co-transfection of VHL and ALK5-HA followed by treatment with TGF- $\beta$, or overexpression of VHL alone, followed by treatment with TGF- $\beta$ significantly reduced the invasiveness of cells when compared with cells transfected with $A L K 5$ - $H A$ followed by treatment with TGF- $\beta$ (Figure $3 \mathrm{E}, \mathrm{n}=3$ independent experiments). In the absence of TGF- $\beta$ treatment, cells transfected with VHL showed reduced invasion when compared with cells transfected with pcDNA control of ALK5 (Supplementary Figure 2, $\mathrm{n}=3$ independent experiments). These results showed that the pVHL negatively regulated the TGF- $\beta$ induced invasiveness in A498 cells.

In ACHN cells, TGF- $\beta$ treatment did not induce the invasiveness of cells transfected with siRNA control. However, overexpression of ALK5-HA and followed by TGF- $\beta$ treatment significantly increased the invasiveness of cells when compared with untreated control cells, or cells transfected with siRNA control and treated with TGF- $\beta$. These results revealed that the presence of wildtype $V H L$ reduced the invasiveness induced by TGF- $\beta$, while overexpression of ALK 5 and treatment with TGF- $\beta$ increased the invasiveness. Importantly, knockdown of $V H L$ through siRNA followed by TGF- $\beta$ stimulation, significantly increased the invasiveness of cell. This result indicated that knockdown of $V H L$ alone is sufficient to sensitize ACHN cells to TGF- $\beta$ stimulation (Figure 3F, $\mathrm{n}=3$ independent experiments).

Collectively, these results showed that both the wild-type $V H L$ and re-introduced $V H L$, will render cells unresponsive to invasiveness due to TGF- $\beta$ treatment for 24 hours.

\section{pVHL associates with ALK5}

To explore the possibility of a functional interaction between $\mathrm{pVHL}$ and ALK5 proteins, A498 cells were cotransfected with $A L K 5-H A$ and $V H L$ followed by TGF- $\beta$ 
Table 4: Relation of ALK5-FL, ALK5-ICD, pSMAD2/3 and PAI-1 protein levels to categorized clinicopathological parameters in ccRCC VHL-High

\begin{tabular}{|c|c|c|c|c|c|c|c|c|c|c|c|c|}
\hline \multirow[b]{2}{*}{ Parameter } & \multicolumn{3}{|c|}{ ALK5-FL } & \multicolumn{3}{|c|}{ ALK5-ICD } & \multicolumn{3}{|c|}{ pSMAD2/3 } & \multicolumn{3}{|c|}{ PAI-1 } \\
\hline & $\mathbf{n}^{\mathbf{a}}$ & $\begin{array}{l}\text { Mean } \\
\text { Rank }\end{array}$ & $P$-Value ${ }^{b}$ & $\mathbf{n}^{\mathbf{a}}$ & $\begin{array}{l}\text { Mean } \\
\text { Rank }\end{array}$ & $P$-Value ${ }^{\text {b }}$ & $\mathbf{n}^{\mathrm{a}}$ & $\begin{array}{l}\text { Mean } \\
\text { Rank }\end{array}$ & $P$-Value ${ }^{b}$ & $\mathbf{n}^{\mathrm{a}}$ & $\begin{array}{l}\text { Mean } \\
\text { Rank }\end{array}$ & $\begin{array}{c}P \text { - } \\
\text { Value }^{\text {b }}\end{array}$ \\
\hline \multicolumn{13}{|l|}{ Grade } \\
\hline \multirow[t]{2}{*}{$\mathrm{I}(\mathrm{I}+\mathrm{II})$} & 34 & 35.78 & & 34 & 32.24 & & 34 & 33.47 & & 34 & 30.13 & \\
\hline & & & 0.911 & & & 0.206 & & & 0.416 & & & 0.032 \\
\hline II (III+IV) & 36 & 35.24 & & 36 & 38.49 & & 36 & 37.42 & & 36 & 40.57 & \\
\hline \multicolumn{13}{|l|}{ TNM Stage } \\
\hline \multirow[t]{2}{*}{ Early Stage $(\mathrm{I}+\mathrm{II})$} & 37 & 34.12 & & 37 & 30.11 & & 37 & 35.20 & & 37 & 29.46 & \\
\hline & & & 0.548 & & & 0.019 & & & 0.897 & & & 0.009 \\
\hline $\begin{array}{l}\text { Advanced Stage } \\
(\mathrm{III}+\mathrm{IV})\end{array}$ & 33 & 37.05 & & 33 & 41.55 & & 33 & 35.83 & & 33 & 42.27 & \\
\hline \multicolumn{13}{|l|}{ Tumor size (mm) } \\
\hline \multirow[t]{2}{*}{$<70$} & 29 & 38.47 & & 29 & 37.62 & & 29 & 36.03 & & 29 & 36 & \\
\hline & & & 0.305 & & & 0.463 & & & 0.853 & & & 0.863 \\
\hline$>70$ & 41 & 33.40 & & 41 & 34 & & 41 & 35.12 & & 41 & 35.15 & \\
\hline
\end{tabular}

a Number of patients.

${ }^{\mathrm{b}}$ Groups were compared using Mann-Whitney $U$ test (significant at $P<0.05$ ).

treatment, and ACHN cells were transfected with ALK5$H A$ followed by TGF- $\beta$ treatment. Immunoprecipitation was performed in both cell lines with either $H A$ or $V H L$, and the results showed that $\mathrm{pVHL}$ co-immunoprecipitated with ALK5 in both cases (Figure 4A, 4B, Supplementary Figure 3A and Supplementary Figure 3B).

The proximity ligation assay (PLA) was used to investigate if pVHL and ALK5 can be found to associate in a protein complex in ccRCC cells. In PLA experiments, A498 cells co-transfected with VHL and ALK5-HA showed prominent PLA signals, while control cells had no signal (Figure 4C). ACHN cells transfected with ALK5HA showed higher PLA signals than the control cells (Figure 4D).

Collectively, these results indicated that ALK5 and pVHL are associating with each other in ccRCC cells.

\section{pVHL mediates proteasomal degradation of ALK5 by ubiquitination}

To elucidate if proteasomal degradation of ALK5 was mediated by VHL, A498 cells were co-transfected with $V H L$ and $A L K 5-H A$ vectors, and ACHN cells were transfected with $A L K 5-H A$. After transfection, both cell lines were treated with either TGF- $\beta$ or MG132 along with TGF- $\beta$. MG132, a well-known proteasomal inhibitor, inhibited proteasomal activity and increased the stability of ALK5 protein compared with the MG132 untreated cells (Figure 4E and 4F).

To validate K48-ubiquitination, an In-vivo ubiquitination assay was performed in A498 and ACHN cells.

A498 $\left(\mathrm{VHL}^{-/}\right)$cells were subjected to immunoprecipitation after co-transfection of $A L K 5-H A$ and $V H L$ vectors followed by TGF- $\beta$ treatment. The results verified K48-linked ubiquitination of ALK5 in cells transfected with $A L K 5-H A$ and $V H L$ when compared with cells transfected with $p c D N A$ or cells transfected with ALK5-HA alone (Figure 4G, Supplementary Figure 4A).

In addition, in situ PLA experiment was performed on A498 cells ( $\mathrm{VHL}^{-/}$) after $A L K 5-H A$ overexpression. In the absence of pVHL, A498 cells showed no PLA signal (proximity of $\mathrm{K} 48$ and HA) in both control and $A L K 5$ $H A$ transfected cells treated with TGF- $\beta$. Further, the introduction of $V H L$ along with $A L K 5-H A$ in A498 (VHL${ }^{-}$) cells showed a strong PLA signal (K48 and HA) (Figure 4H).

In ACHN cells, $A L K 5-H A$ vector was transfected into cells, and treated with TGF- $\beta$. Following immunoprecipitation, K48-linked ubiquitination of ALK5 was also observed. Knock-down of $V H L$ by siRNA reduced the K48-linked poly-ubiquitination of transiently over-expressed ALK5-HA, which confirmed pVHL dependent K48-linked ubiquitination of ALK5 (Figure 4I, Supplementary Figure 4B).

To support the data achieved in the ubiquitination assay, in situ PLA was performed in ACHN cells ( $\mathrm{VHL}^{+/+}$) after transfecting $A L K 5-H A$ followed by TGF- $\beta$ treatment. Cells transfected with $A L K 5-H A$ showed significantly higher PLA signals (proximity of K48 and HA) than the control cells (Figure 4J).

Additional experiment in ACHN cells confirmed that the VHL enhanced the ubiquitination of ALK5-FL after co-transfection of HA-tagged ubiquitin and ALK5GST (Supplementary Figure 5).

In summary, these results indicated VHL dependent K48-linked ubiquitination of ALK5 in ccRCC cell lines in response to TGF- $\beta$. 

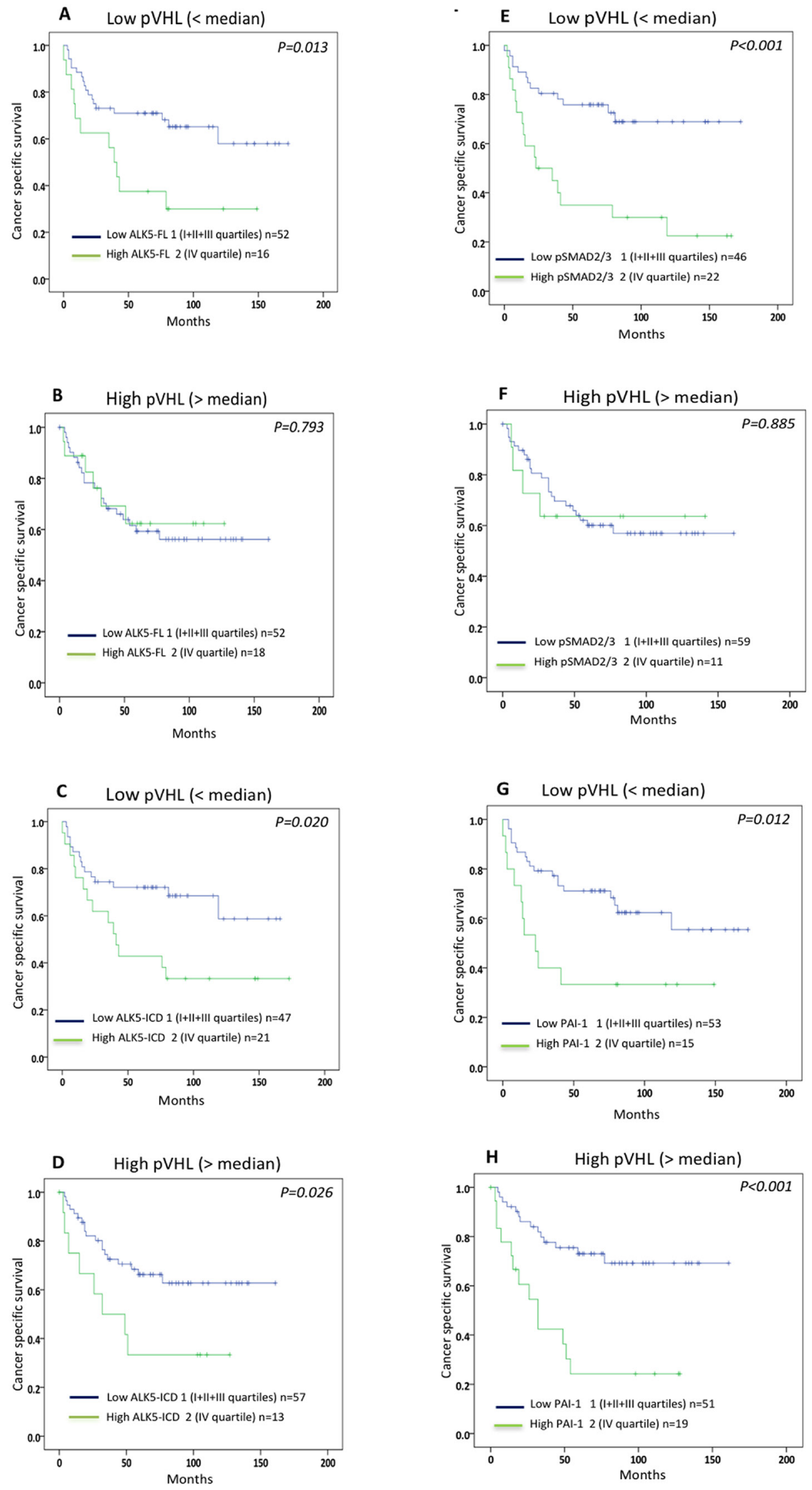

Figure 2: Kaplan-Meier plots showing cancer-specific survival curves of (A, B) ALK5-FL; (C, D) ALK5-ICD; (E, F) pSMAD2/3; (G, H) PAI-1 protein levels in ccRCC VHL- Low and ccRCC VHL-High. 


\section{DISCUSSION}

In the present study, we have investigated the functional role of $\mathrm{pVHL}$ status on TGF- $\beta$ signaling in nonccRCC as well as in ccRCC. We found that the expression of the pVHL level, in ccRCC, was significantly lower compared with non-ccRCC. The finding of similar $\mathrm{pVHL}$ levels in non-ccRCC and non-malignant kidney cortex tissues indicate that pVHL was not altered in non-ccRCC. This result is in line with the previous study [27]. Similar to earlier studies [28-30], the expression levels of pVHL in ccRCC (undivided), the subgroup of ccRCCs pVHLLow, ccRCCs pVHL-High as well as in non-ccRCC, showed no association with clinicopathological factors. Although the mutation or deletion of $V H L$, is a promoting factor in the ccRCC type, $V H L$ alone is not sufficient for tumor progression in RCCs [31].

Our recent study, on ccRCC, reported that increased expressions of components in canonical TGF- $\beta$ signaling and in particular AlK5-ICD, a non-canonical pathway component, have a pivotal role in driving the aggressiveness of the tumors, occurrence of metastasis, and survival of the patients [25]. In the present study, we showed that the expression levels of the TGF- $\beta$ signaling components, ALK5-FL and pSMAD2/3, neither were associated with clinicopathological parameters nor with the survival of non-ccRCC patients. Conversely, TGF- $\beta$ signaling components were significantly involved in tumor progression and cancer-specific survival of ccRCC pVHL-Low patients. These findings strongly suggest that the status of $p V H L$ dictates the TGF- $\beta$ signaling $[13,14]$. Although ccRCC pVHL-High showed clear cell histology, we observed that they deviated from the ccRCC pVHL-Low, regarding regulation of the TGF- $\beta$ signaling pathway. One of the major differences between ccRCC and non-ccRCC is the levels of pVHL. It is also well known that around $50-70 \%$ of sporadic ccRCC have VHL gene aberration, while the remaining $30-40 \%$ of ccRCC occur with intact pVHL [32]. Apparently, ccRCC patients with an intact $V H L$ gene set will mostly have

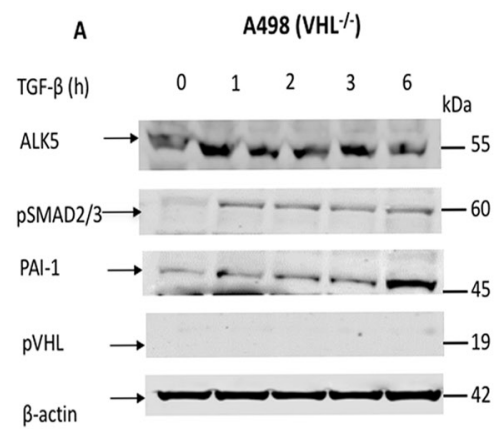

B $\operatorname{ACHN}\left(\mathrm{VHL}^{+/+}\right)$

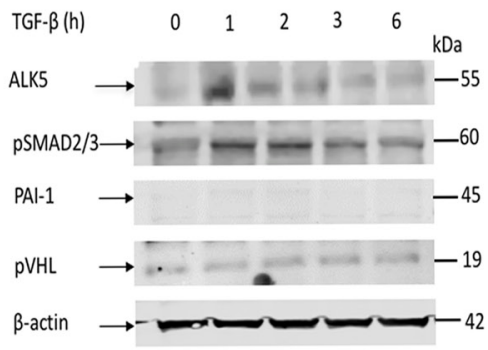

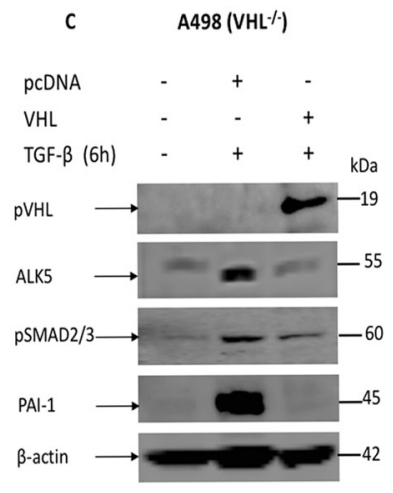

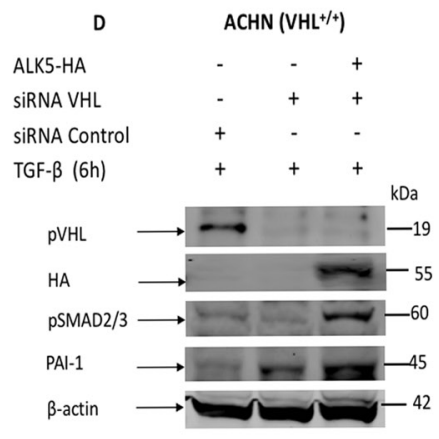

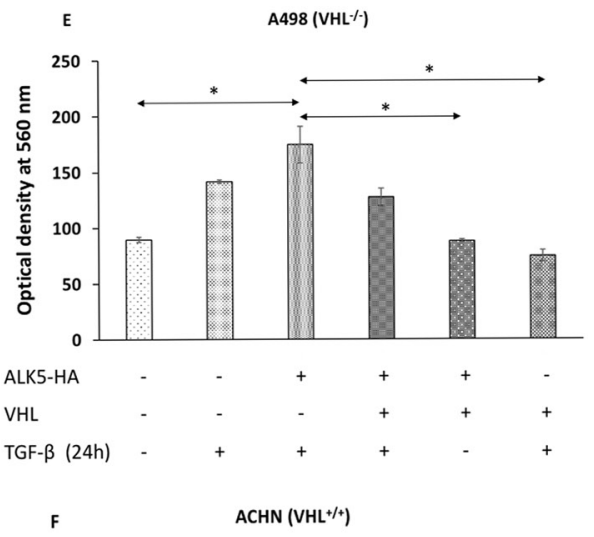

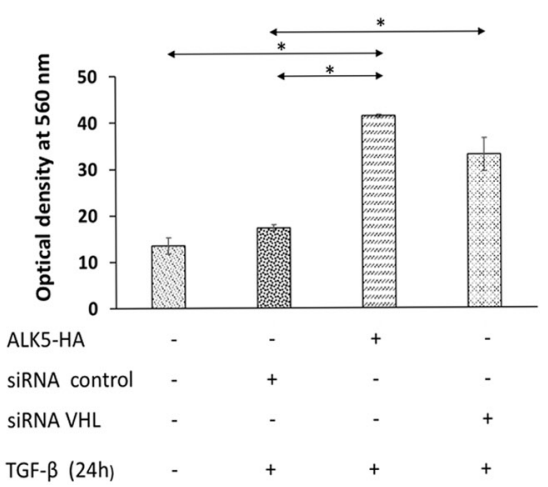

Figure 3: (A) Immunoblots showing protein expression of ALK5, pSMAD2/3, PAI-1, pVHL, and $\beta$-actin in A498 cells after treatment with TGF- $\beta$ at given point of time; (B) Immunoblots showing protein expression of ALK5, pSMAD2/3, PAI-1, pVHL, and $\beta$-actin in ACHN cells after treatment with TGF- $\beta$ at given point of time; (C) Immunoblots showing protein expression of pVHL, ALK5, pSMAD2/3, PAI-1, and $\beta$-actin after transfection of indicated vectors in A498 cells followed by TGF- $\beta$ treatment for 6 hours; (D) Immunoblots showing protein expression of pVHL, HA, pSMAD2/3, PAI-1, and $\beta$-actin after transfection of indicated vectors in ACHN cells (48h) followed by TGF- $\beta$ treatment for 6 hours; (E) Invasion assay showing the invasiveness induced by TGF- $\beta$ in A498 cells after re-introduction of $V H L$ $\left(\mathrm{n}=3\right.$ independent experiments $\left.{ }^{*} \mathrm{P}<0.05\right)$; (F) Invasion assay showing invasiveness by TGF- $\beta$ in ACHN cells after siRNA VHL knockdown $\left(\mathrm{n}=3\right.$ independent experiments $\left.{ }^{*} \mathrm{P}<0.05\right)$. 
A
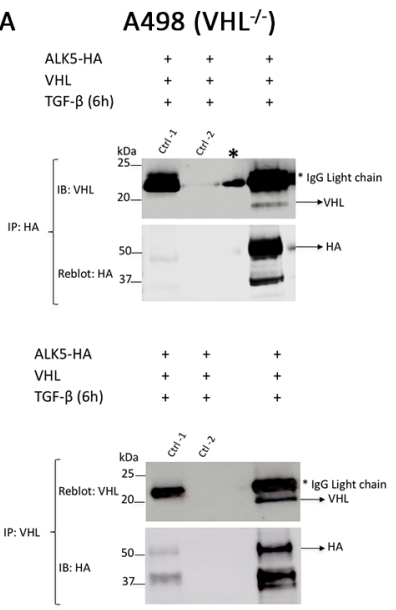

F $\mathrm{ACHN}\left(\mathrm{VHL}^{+/+}\right)$

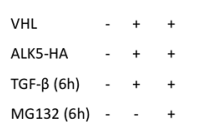

MG132 (6h) - .

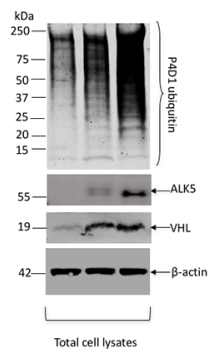

Total cell lysates
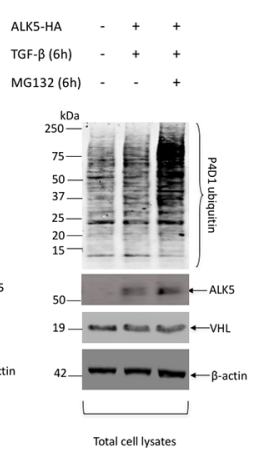

B
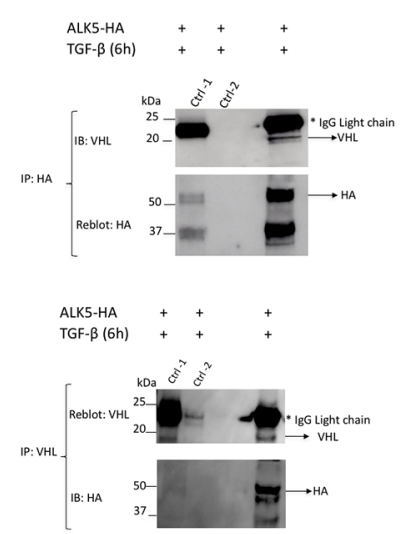

C

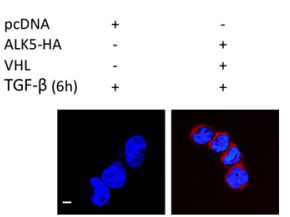

D ACHN $\left(\mathrm{VHL}^{+/+}\right)$

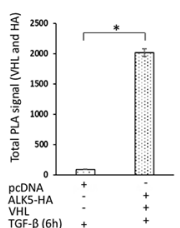

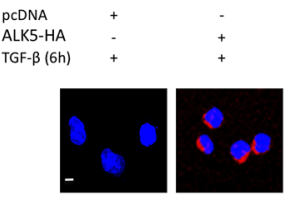

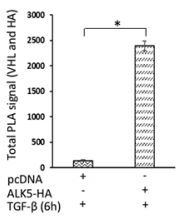

I

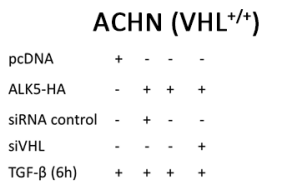

kDa

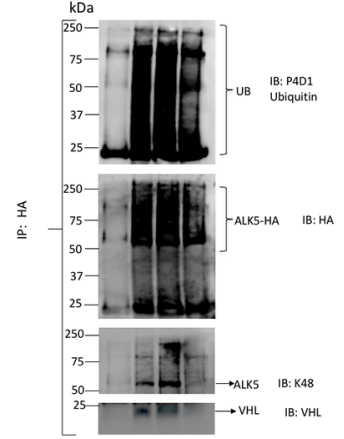

G

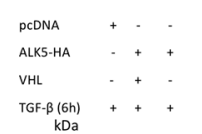

kDa

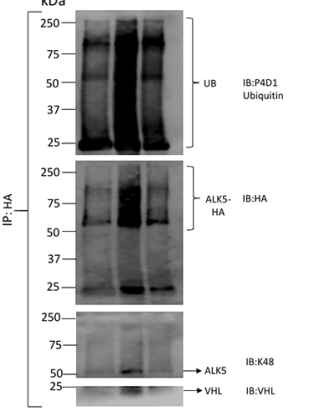

$\operatorname{ACHN}\left(\mathrm{VHL}^{+/+}\right)$
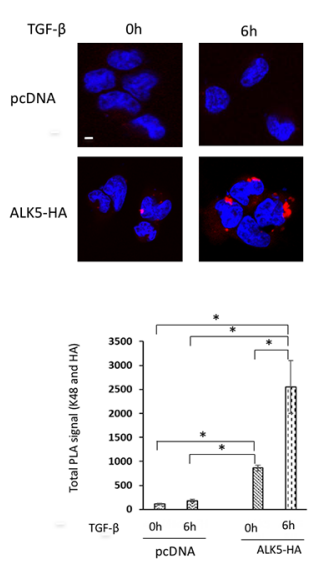

H

A498 $\left(\mathrm{VHL}^{-1-}\right)$

TGF- $\beta$

PCDNA
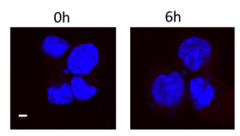

ALK5-HA
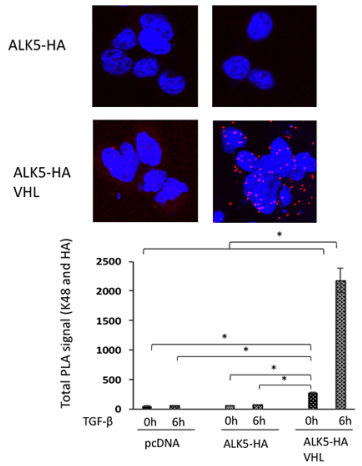

Figure 4: (A) Immunoblots showing IP with HA or VHL antibody: A498 cells were co-transfected with $A L K 5$ - $H A$ and $V H L$ vectors, followed by TGF- $\beta$ treatment for $6 \mathrm{~h}$, and probed with HA or VHL antibody, respectively $\left({ }^{*}\right.$ indicates a spill, Ctrl-1 is isotype specific IgG plus beads, Ctrl -2 is beads only); (B) Immunoblots showing IP with HA or VHL antibody: ACHN cells were transfected with ALK5$H A$ vector, followed by TGF- $\beta$ treatment for $6 \mathrm{~h}$, and probed with HA or VHL antibody, respectively (Ctrl-1 is isotype specific IgG plus beads, Ctrl -2 is beads only); (C) A498 cells were transiently co-transfected with $A L K 5-H A$ and $V H L$ vectors or pcDNA 3. 1(+) empty vector, followed by TGF- $\beta$ treatment for $6 \mathrm{~h}$, and pVHL-ALK5-HA complexes was visualized by staining cells after probing against VHL and HA (red) antibodies followed by PLA. Scale bar $20 \mu \mathrm{m}$ (mean \pm SD of three experiments, 100 cells were analyzed in each group);

(Continued) 
Figure 4 (Continued): (D) ACHN cells were transfected with $A L K 5-H A$ or $p c D N A 3.1(+)$ empty vector, followed by TGF- $\beta$ treatment for $6 \mathrm{~h}$, and pVHL-ALK5-HA complexes was visualized by staining cells after probing against VHL and HA (red) antibodies followed by PLA. Scale bar $20 \mu \mathrm{m}$ (mean \pm SD of three experiments, 100 cells were analyzed in each group); (E) Immunoblot (total cell lysates) showing inhibition of proteasomal degradation by proteasomal inhibitor MG132: A498 cells were transfected with ALK5-HA and VHL followed by treatment with TGF- $\beta$, or treatment of TGF- $\beta$ along with MG132 for 6 hours; (F) Immunoblot (total cell lysates) showing inhibition of proteasomal degradation by proteasomal inhibitor MG132: ACHN cells were transfected with $A L K 5-H A$, followed by treatment with TGF- $\beta$ or treatment with TGF- $\beta$ along with MG132 for 6 hours; (G) pVHL mediates K48-linked poly-ubiquitination of ALK5: Immunoblot showing enhanced K48-linked poly-ubiquitination of ALK5 by VHL, A498 cells were transfected with indicated plasmids followed by treatment of TGF- $\beta$ for 6 hours then immunoprecipitated with HA antibody and immunoblot with indicated antibody; (H) PLA analysis and quantification of PLA signals (K48 and HA) in A498 cells transfected with $p c D N A$ 3.1(+) empty vector, $A L K 5-H A$ vector alone, or cotransfected with $A L K 5-H A$ and $V H L$ vectors (mean \pm SD of two experiments, 150 cells were analyzed in each group); (I) pVHL mediates K48-linked poly-ubiquitination of ALK5: Immunoblot showing enhanced K48-linked poly-ubiquitination of ALK5 by VHL, ACHN cells were transfected with indicated plasmids followed by treatment of TGF- $\beta$ for 6 hours then immunoprecipitated with HA antibody and immune blot with indicated antibody; (J) PLA analysis and quantification of PLA signals (K48- and HA) in ACHN cells transfected with pcDNA 3.1(+) empty vector, ALK5-HA (mean $\pm \mathrm{SD}$ of two experiments, 150 cells were analyzed in each group).

unaffected pVHL. This fact is confirmed in the present study showing that a proportion of ccRCC, despite clear cell histology, has pVHL levels similar to the nonmalignant kidney cortex and of non-ccRCCs that have no $V H L$ deletion. This knowledge seems to be essential for choosing the treatment of RCC with targeting agents. Most of the patients with ccRCC are affected by treatment of targeting agents, while the effects of treatment on other RCCs and also non-ccRCCs are diminished [33]. Thus, the expression of TGF- $\beta$ signaling components had no association to the occurrence of metastasis and survival of the patients in ccRCC pVHL-High like non-ccRCC. Altogether, our data imply that the aggressive tumor properties regulated by TGF- $\beta$ signaling depend on the $\mathrm{pVHL}$ status in RCC. This outcome gave an indication of a possible association between expression of $\mathrm{pVHL}$ and expression of ALK5-FL.

Notably, in ccRCC pVHL-High, expression of PAI1 and ALK5-ICD were found to be independent of VHL status, unlike ALK5-FL and pSMAD2/3. The expression of PAI-1 was observed to be correlated with the tumor grade and survival status of the patient. These results indicate that the PAI-1 expression is regulated by multiple pathways as previously reported [34]. Since expression of ALK5-ICD was associated with the tumor stage and survival in ccRCC pVHL-High and pVHL-Low, this indicates that occurrence of high ALK5-ICD promotes poor prognosis independent of $\mathrm{pVHL}$ status. These results might also indicate that ALK5-ICD is independent of pVHL status because the occurrence of the ALK5-ICD does not follow the SMAD-dependent pathway [19].

Previous studies have shown that TGF- $\beta$ seems to be the target of $V H L$, but the exact mechanism was not revealed $[13,14]$. The relation between $p V H L$ status and TGF- $\beta$ signaling in the clinical materials in this study was further verified by in-vitro cell lines studies. By overexpression versus knock-down of $V H L$, the expression of endogenous pVHL was observed to affect TGF- $\beta$ signaling as well as invasive properties of ccRCC cells. We also noticed that the endogenous pVHL negatively regulated the TGF- $\beta$ signaling pathway. The in-vitro experiment data presented in this study showed that the knocking down of $V H L$ induced the downstream targets of TGF- $\beta$ pathway such as PAI- 1 , and the presence of intact wild-type $V H L$ inhibited the PAI-1 expression driven by TGF- $\beta$ stimulation. Intriguingly, the presence of $\mathrm{pVHL}$ inversely regulated the TGF- $\beta$ dependent cell invasion. In-vitro studies, performed in ccRCC cell lines, also showed that the pVHL interacted with ALK5, indicating that $\mathrm{pVHL}$ thereby might regulate the protein stability of ALK 5 , consequently controlling the TGF- $\beta$ signaling through proteasomal degradation of ALK5 by K48-linked poly-ubiquitination. This result is supported by previous studies that pVHL can act as an E3 ubiquitination ligase, and mediates K48-linked poly-ubiquitination, and subsequent proteosomal degradation of other proteins $[8,9,12]$. Collectively, the in-vitro studies, performed in this report, supported data achieved in the clinical study, by showing that the invasiveness and progression of RCC were dictated by the tumor suppressor $V H L$, by revoking the TGF- $\beta$ signaling pathway.

In conclusion, the novel findings presented in this study, are relevant for the understanding of the effects of systemic treatments of RCC types depending on the pVHL status. Current tyrosine kinase inhibitors have inferior effect in non-ccRCC compared with ccRCC $[33,35]$. It is possible that the difference in therapy response, in part, might be associated with the status of TGF- $\beta$ signaling and the expression of ALK5-ICD. Molecular analysis of individual patient's tumors with respect to expression of ALK5-ICD and pVHL status can give additional information that might be useful for planning of the personalized treatment for patients with RCC.

\section{MATERIALS AND METHODS}

\section{Patients}

The study included 143 (63 male and 80 female) patients with ccRCC surgically treated between 2000 and 2009 and 58 (20 male and 38 female) patients with non-ccRCC surgically treated between 1988 and 2009. 
For ccRCC, the median age was 65.11 years (range 32-85 years), and the mean tumor size was $70 \mathrm{~mm}$ (range 12$190 \mathrm{~mm}$ ). For non-ccRCC, the median age was 68 years (range 32-85 years) and the mean tumor size was $70 \mathrm{~mm}$ (range 10-190 mm) [36, 37]. Tumor size was defined as the maximum diameter determined by CT. Samples from tumor and kidney cortex tissues from the tumor-bearing kidney were obtained after nephrectomy as described previously [38]. All samples were collected after obtaining informed and authorized consent from the patients. The study was approved by the institutional review board and the ethical committee of Northern Sweden.

Tumor stage was determined following the TNM classification system 2009 [39]. In ccRCC, there were 55 patients in TNM stage I (38.46\%), 24 patients in stage II $(16.78 \%), 27$ patients in stage III (18.89\%), and 37 patients in stage IV (25.87\%). In non-ccRCC, there were $25(43.10 \%)$ patients in TNM stage I, $15(25.86 \%)$ patients in stage II, 9 $(15.5 \%)$ patients in stage III, and $9(15.5 \%)$ patients in stage IV. Nuclear grade was determined according to Fuhrman et al. [40]. In ccRCC, there were 16 tumors as $(11.18 \%)$ grade 1, $56(39.16 \%)$ tumors as grade 2, $45(31.46 \%)$ tumors as grade 3 , and $26(18.18 \%)$ tumors as grade 4 . In non-ccRCC, $5(8.62 \%)$ tumors were grade $1,28(48.27 \%)$ tumors as grade 2, $18(31.03 \%)$ tumors as grade 3, and $7(12.06 \%)$ tumors as grade 4 . The RCC type was classified according to the Heidelberg consensus conference [1]. For statistical use, stage I and stage II were considered as early stage, and stage III and stage IV were considered as advanced stage. Similarly, grade I and II were considered as low grade and grade III and grade IV were considered as higher grade.

Patient follow-up performed in a scheduled program was used for survival analysis. At the last follow-up, 55 (38.40\%) patients with ccRCC were alive without any indication of disease, $6(4.2 \%)$ were alive with disease, 57 (39.9\%) died of the disease, and $25(17.5 \%)$ died due to other reasons. For non-ccRCC, 20 patients (34.5\%) were alive without disease, $1(1.7 \%)$ were alive with disease, $20(34.5 \%)$ died of the disease, and 17 (29.30\%) died due to other reasons.

\section{Protein extraction and analysis}

Proteins from clinical samples were extracted as described previously [25]. Proteins from in-vitro studies were obtained by scraping the adherent cells with Radioimmunoprecipitation assay buffer (RIPA buffer), spun down at $10000 \mathrm{rpm}$ for 10 minutes at $4^{\circ} \mathrm{C}$, and the supernatant which consisted of proteins was collected. Proteins were analyzed using the bicinchoninic acid assay (BCA assay) (Thermo Fisher Scientific, Waltham, MA, USA) following the manufacturer's guidelines.

\section{Immunoblot (IB)}

Total proteins $(30 \mu \mathrm{g})$ were separated by NuPAGE Novex $10 \%$ gels or NuPAGE Novex 12\% gels (Life
Technologies, Carlsbad, CA, USA) in XCell SureLock ${ }^{\mathrm{TM}}$ Mini-Cell (Life Technologies), and transferred onto nitrocellulose membrane using Transblot Turbo transfer system (Bio-Rad Laboratories, Hercules, CA, USA). Based on the antibodies, the membranes were blocked in $5 \%$ BSA or $5 \%$ non-fat milk or Odyssey blocking buffer (Licor Biosciences, Lincoln, NE, USA) diluted in TrisBuffered Saline, for 1 hour at room temperature. The membranes were incubated overnight at $4{ }^{\circ} \mathrm{C}$ with gentle agitation with the indicated primary antibodies;

TGF-ßRI (or ALK5, V-22) (sc-398, Santa Cruz Biotechnology, Santa Cruz, CA, USA), which identifies ALK5-FL and ALK5-ICD, as previously reported [19], HA (CST \#2367 and CST \#3724, Cell Signaling Technology, Danvers, MA, USA), HA (12CA5, Roche, Basel, Switzerland), phospho-SMAD2 (CST \#3108, Cell Signaling Technology), PAI-1/Serpine1 (NBP119773, Novus Biologicals, Littleton, CO, USA), VHL (VHL40 (in vitro studies), Santa Cruz Biotechnology), VHL (NB100-485 (Human clinical sample), Novus Biologicals), K48-linkage Specific (CST \#4289, Cell Signaling Technology), K48-linkage Specific (ab140601, Abcam, Cambridge, United Kingdom), P4D1 Ubiquitin (CST \#3936, Cell Signaling Technology) and $\beta$-actin (A5316, Sigma-Aldrich, St. Louis, MO, USA). The primary antibodies were detected using secondary antibody IRDye ${ }^{\circledR}$ 800CW Goat Anti-Rabbit (Licor \#92632211 , Licor Biosciences) or IRDye ${ }^{\circledR} 680 \mathrm{CW}$ Goat antimouse (Licor \#925-68070, Licor Biosciences). Odyssey CLx (Licor Biosciences) Infrared Imaging system was used to visualize the membranes, and Image Studio System $^{\mathrm{TM}}$ software version 3.1 (Licor Biosciences) was utilized for densitometry. The relative numerical density values for all the proteins were calculated by dividing the density value of housekeeping protein $\beta$-actin.

\section{In-vitro cell culture studies}

All cell lines utilized in this study were mycoplasma free, and used within five passages. The cells were authenticated by STR profiling (IdentiCell, Denmark). Two ccRCC cell lines, A498 (VHL $\left.{ }^{-/}\right)$and ACHN $\left(\mathrm{VHL}^{+/+}\right)$, were bought from ATCC (Wesel, Germany). A498 and ACHN cells were cultured in RPMI (SigmaAldrich) and E-MEM (ATCC) respectively (supplemented with $10 \% \mathrm{FBS}$ ). ACHN and A498 were seeded into $10 \mathrm{~cm}$ plates at $1 \times 10^{6}$ cells.

A498 and ACHN cells were treated with TGF- $\beta 1$ (R\&D system, UK) (10 ng/ml) for $1 \mathrm{~h}, 2 \mathrm{~h}, 3 \mathrm{~h}$, and $6 \mathrm{~h}$.

A498 and ACHN cells were transfected with C-terminally hemagglutinin (HA)-tagged ALK5 (ALK5$H A)$ or $p c D N A 3.1(+)$ or $A L K 5-H A$ [19] and $V H L$ (NM_000551.2, Origene Technologies, Inc., Rockville, MD, USA) using Lipofectamine 3000 (Thermo Fisher Scientific) following the manufacturer's instructions. The next day, cells were starved for 12 hours, then treated with TGF- $\beta$ for 6 hours, followed by protein extraction. 
To knockdown $V H L$, ACHN cells were transfected with siRNA VHL purchased from Ambicon (Cat \#:4390824, ThermoFisher Scientific) or co-transfected with siRNA VHL and ALK5-HA. VHL siRNA $(75 \mu \mathrm{M})$ were transfected using RNAimax (ThermoFisher Scientific) by following manufacturer's guidelines. After 72 hours of transfection, the cells were treated with TGF- $\beta$ for 6 hours. The proteins were then collected.

For immuno-precipitation, $A L K 5-H A$ and $V H L$ were co-transfected to A498 cell line, and ALK5-HA was transfected to ACHN cell line, both the cell lines were treated with TGF- $\beta$ for 6 hours. Either $V H L$ or HA, was immunoprecipitated from the total cell lysate using indicated antibody. Immunoblots were then probed with either HA or VHL antibody. Later, the blots were reprobed with antibody against the immunoprecipitated proteins. The primary antibodies were detected by light chain specific anti-rabbit and anti-mouse IgG antibodies conjugated with horse radish peroxidase (Jackson ImmunoResearch Laboratories, West Grove, PA, USA) and visualized by Chemiluminescence (ECL-select, Amersham Biosciences, UK).

To investigate the potential of proteasomal degradation of ALK5, A498 cells were co-transfected with $A L K 5-H A$ and $V H L$, and ACHN cells were transfected with $A L K 5-H A$, the following day, cells were treated with TGF- $\beta$ (10 ng/ml) or TGF- $\beta$ along with MG132 (15 $\mu \mathrm{M})$ (Sigma-Aldrich) for 6 hours, and cells lysates were collected.

\section{Proximity ligation assay (PLA)}

For PLA experiment to visualize protein-protein interaction, A498 $\left(5 \times 10^{5}\right)$ and $\mathrm{ACHN}\left(5 \times 10^{5}\right)$ cells were seeded onto two well chamber slide one day before transfection. A498 cells were then co-transfected with $A L K 5-H A$ and VHL or transfected with $p c D N A$ $3.1(+)$ empty vector as a control, and ACHN cells were transfected with $A L K 5-H A$ or transfected with pcDNA3.1(+) empty vector as a control. In another set of experiments, A498 cells were transfected with $A L K 5-H A$, or co-transfected $A L K 5-H A$ and $V H L$ vectors, or transfected with $p c D N A 3.1(+)$ empty vector as a control. ACHN cells were transfected with $A L K 5-H A$ or transfected with $p c D N A 3.1(+)$ empty vector as a control, after 24 hours, the cells were treated with TGF- $\beta$ (10 ng/ $\mathrm{ml}$ ) for 6 hours.

PLA was performed according to manufacturers' instructions (Sigma-Aldrich). In short, the cells were washed with PBS, fixed using 4\% formaldehyde and permeabilized using Triton-X. The cells were blocked with $5 \%$ BSA in $0.2 \%$ Triton-X. After blocking, the cells were incubated with HA antibody (CST \#3724, Cell Signaling Technology) and VHL G7 antibody (SC-17780, Santa Cruz Biotechnology) or HA antibody (CST \#2367, Cell Signaling Technology) and K48 (ab140601, Abcam) for 24 hours in a humidity chamber at $4^{\circ} \mathrm{C}$. The cells were washed with PBS and incubated with rabbit plus and mouse minus probes. Detection of PLA signal was performed using the kit purchased from Sigma-Aldrich. Slides were scanned using a confocal microscope Zeiss 710 Meta (Carl Zeiss MicroImaging, Inc.) and zen-2010 software. The Images were acquired at $40 \mathrm{X}$ and $63 \mathrm{X}$. The images were analyzed and represented graphically using Duolink Image Tool (Sigma-Aldrich).

\section{Invasion assay}

Invasion assay kit was purchased from Cell Biolabs (CBA-110-COL, San Diego, CA, USA), and the assay was performed according to the manufacturer's protocol. In short, 48 hours after transfection, cells were starved, trypsinized and added to the upper chamber of invasion assay containing media with $2 \% \mathrm{FBS}$, and the wells were filled with media with $10 \%$ FBS, the cells were stimulated with TGF- $\beta$ (10 ng/ml), unstimulated cells served as controls. The cells were stained and eluted, and the resulting solution's optical density (OD) was measured at $560 \mathrm{~nm}$. Cells were visualized under a Leitz light microscope (Germany) at magnification 10X. Images were captured using DpxViewPro software (Denmark).

\section{In-vivo ubiquitination assay}

A498 and ACHN Cells $\left(5 \times 10^{6}\right)$ were seeded one day before transfection. A498 cells were transfected with pcDNA 3.1(+) or co-transfected with $A L K 5-H A$ and $V H L$ or transfected with $A L K 5-H A$ alone. ACHN cells were transfected with $p c D N A 3.1(+)$ or co-transfected with siRNA control and $A L K 5-H A$ or transfected with ALK5-HA or co-transfected with siVHL and ALK5-HA using Lipofectamine 3000 (Thermo Fisher Scientific) following the manufacturer's instructions. After 24 hours following transfection, cells were starved, and treated with TGF- $\beta$ for 6 hours, and then cell pellets were collected. In brief, cell pellets were boiled at $95^{\circ} \mathrm{C}$ in $200 \mu \mathrm{l}$ of PBS containing 1\% SDS for 10 minutes. After boiling, 1800 $\mu \mathrm{l}$ PBS with $0.5 \%$ NP-40 along with A-protein (1:100) and Pefabloc $(1: 200)$ was added. The samples were then centrifuged at $13000 \mathrm{rpm}$ for 10 minutes at $4^{\circ} \mathrm{C}$. Then the supernatants were subjected to immunoprecipitation, followed by immunoblotting. Ubiquitination assay was performed as previously described [41].

\section{Statistical analysis}

For clinical studies, statistical analysis was performed utilizing IBM SPSS Statistics 24.0. For the cell culture experiments the Student's t-test was used. The difference in expression of two independent variables was analyzed by the Mann-Whitney U-test. Kaplan-Meier curves were used to express survival times, and the log-rank test was used to 
compare the survival times. For all the tests, a $P$ value less than 0.05 was considered significant.

\section{Author contributions}

P.M. and T.S.R. contributed equally to this work. T.S.R. coordinated the project and prepared the manuscript with the help of P.M. M.L., and B.L.J. contributed equally as last authors and supervised to draft the manuscript. All authors analyzed and discussed the data.

\section{ACKNOWLEDGMENTS}

We thank Ms. Britt-Inger Dahlin, Ms. Kerstin Almroth, the staff in Urology and Andrology at Umeå University Hospital for skillful technical assistance, and the participating patients for their cooperation.

\section{CONFLICTS OF INTEREST}

The authors declare no conflicts of interest.

\section{FINANCIAL SUPPORT}

This study was supported by grants from Umeå University, Lions Cancer Research Foundation in Umeå, and through regional agreement between Umeå University and Västerbottens County Council (ALF), the Swedish Medical Research Council (K2013-66X-15284-04-4), the Swedish Cancer Society (15 0594) and the Knut and Alice Wallenberg Foundation (2012.0090).

\section{REFERENCES}

1. Kovacs G, Akhtar M, Beckwith BJ, Bugert P, Cooper CS, Delahunt B, Eble JN, Fleming S, Ljungberg B, Medeiros LJ, Moch H, Reuter VE, Ritz E, et al. The Heidelberg classification of renal cell tumours. J Pathol. 1997; 183:131-3.

2. Ljungberg B, Bensalah $\mathrm{K}$, Canfield $\mathrm{S}$, Dabestani S, Hofmann F, Hora M, Kuczyk MA, Lam T, Marconi L, Merseburger AS, Mulders P, Powles T, Staehler M, et al. EAU guidelines on renal cell carcinoma: 2014 update. Eur Urol. 2015; 67:913-24.

3. Sauter G, Sesterhenn IA, Eble JN, Epstein JI. Pathology and Genetics of Tumours of the Urinary System and Male Genital Organs. IARC Press. 2004.

4. Gudbjartsson T, Hardarson S, Petursdottir V, Thoroddsen A, Magnusson J, Einarsson GV. Histological subtyping and nuclear grading of renal cell carcinoma and their implications for survival: a retrospective nation-wide study of 629 patients. Eur Urol. 2005; 48:593-600.

5. Cheville JC, Lohse CM, Zincke H, Weaver AL, Blute ML. Comparisons of outcome and prognostic features among histologic subtypes of renal cell carcinoma. Am J Surg Pathol. 2003; 27:612-24.

6. Yap NY, Rajandram R, Ng KL, Pailoor J, Fadzli A, Gobe GC. Genetic and Chromosomal Aberrations and Their Clinical Significance in Renal Neoplasms. Biomed Res Int. 2015; 2015:476508.

7. Kovacs G. Molecular genetics of human renal cell tumours. Nephrol Dial Transplant. 1996; 11:62-5.

8. Frew IJ, Krek W. pVHL: a multipurpose adaptor protein. Sci Signal. 2008; 1:pe30.

9. Iwai K, Yamanaka K, Kamura T, Minato N, Conaway RC, Conaway JW, Klausner RD, Pause A. Identification of the von Hippel-lindau tumor-suppressor protein as part of an active E3 ubiquitin ligase complex. Proc Natl Acad Sci U S A. 1999; 96:12436-41.

10. Makino Y, Cao R, Svensson K, Bertilsson G, Asman M, Tanaka H, Cao Y, Berkenstam A, Poellinger L. Inhibitory PAS domain protein is a negative regulator of hypoxiainducible gene expression. Nature. 2001; 414:550-4.

11. Makino Y, Kanopka A, Wilson WJ, Tanaka H, Poellinger L. Inhibitory PAS domain protein (IPAS) is a hypoxiainducible splicing variant of the hypoxia-inducible factor3alpha locus. J Biol Chem. 2002; 277:32405-8.

12. Xue J, Lv DD, Jiao S, Zhao W, Li X, Sun H, Yan B, Fan L, Hu RG, Fang J. pVHL mediates K63-linked ubiquitination of nCLU. PLoS One. 2012; 7:e35848.

13. Ananth S, Knebelmann B, Gruning W, Dhanabal M, Walz G, Stillman IE, Sukhatme VP. Transforming growth factor beta1 is a target for the von Hippel-Lindau tumor suppressor and a critical growth factor for clear cell renal carcinoma. Cancer Res. 1999; 59:2210-6.

14. Bostrom AK, Lindgren D, Johansson ME, Axelson H. Effects of TGF-beta signaling in clear cell renal cell carcinoma cells. Biochem Biophys Res Commun. 2013; 435:126-33.

15. Massague J. TGF-beta signal transduction. Annu Rev Biochem. 1998; 67:753-91.

16. Massague J. TGFbeta in Cancer. Cell. 2008; 134:215-30.

17. Massague J. TGFbeta signalling in context. Nat Rev Mol Cell Biol. 2012; 13:616-30.

18. $\mathrm{Mu}$ Y, Gudey SK, Landstrom M. Non-Smad signaling pathways. Cell Tissue Res. 2012; 347:11-20.

19. Mu Y, Sundar R, Thakur N, Ekman M, Gudey SK, Yakymovych M, Hermansson A, Dimitriou H, BengoecheaAlonso MT, Ericsson J, Heldin CH, Landstrom M. TRAF6 ubiquitinates TGFbeta type I receptor to promote its cleavage and nuclear translocation in cancer. Nat Commun. 2011; 2:330.

20. Gudey SK, Sundar R, Mu Y, Wallenius A, Zang G, Bergh A, Heldin $\mathrm{CH}$, Landstrom M. TRAF6 stimulates the tumorpromoting effects of TGFbeta type I receptor through polyubiquitination and activation of presenilin 1. Sci Signal. 2014; 7:ra2. 
21. Dong C, Zhu S, Wang T, Yoon W, Goldschmidt-Clermont PJ. Upregulation of PAI-1 is mediated through TGF-beta/ Smad pathway in transplant arteriopathy. J Heart Lung Transplant. 2002; 21:999-1008.

22. Fredstorp-Lidebring M, Bendahl PO, Brunner N, Casslen B, Hogberg T, Langstrom-Einarsson E, Willen R, Ferno M. Urokinase plasminogen activator and its inhibitor, PAI-1, in association with progression-free survival in early stage endometrial cancer. Eur J Cancer. 2001; 37:2339-48.

23. Nekarda H, Schmitt M, Ulm K, Wenninger A, Vogelsang H, Becker K, Roder JD, Fink U, Siewert JR. Prognostic impact of urokinase-type plasminogen activator and its inhibitor PAI-1 in completely resected gastric cancer. Cancer Res. 1994; 54:2900-7.

24. Nielsen HJ, Pappot H, Christensen IJ, Brunner N, Thorlacius-Ussing O, Moesgaard F, Dano K, GrondahlHansen J. Association between plasma concentrations of plasminogen activator inhibitor-1 and survival in patients with colorectal cancer. BMJ. 1998; 316:829-30.

25. Sitaram RT, Mallikarjuna P, Landstrom M, Ljungberg B. Transforming growth factor-beta promotes aggressiveness and invasion of clear cell renal cell carcinoma. Oncotarget. 2016; 7: 35917-31. https://doi.org/10.18632/oncotarget.9177.

26. Zubac DP, Wentzel-Larsen T, Seidal T, Bostad L. Type 1 plasminogen activator inhibitor (PAI-1) in clear cell renal cell carcinoma (CCRCC) and its impact on angiogenesis, progression and patient survival after radical nephrectomy. BMC Urol. 2010; 10:20.

27. Shuin T, Kondo K, Torigoe S, Kishida T, Kubota Y, Hosaka M, Nagashima Y, Kitamura H, Latif F, Zbar B, Lerman MI, Yao M. Frequent Somatic Mutations and Loss of Heterozygosity of the Von Hippel-Lindau Tumor-Suppressor Gene in Primary Human Renal-Cell Carcinomas. Cancer Research. 1994; 54:2852-5.

28. Kondo K, Yao M, Yoshida M, Kishida T, Shuin T, Miura T, Moriyama M, Kobayashi K, Sakai N, Kaneko S, Kawakami S, Baba M, Nakaigawa N, et al. Comprehensive mutational analysis of the VHL gene in sporadic renal cell carcinoma: relationship to clinicopathological parameters. Genes Chromosomes Cancer. 2002; 34:58-68.

29. Schraml P, Struckmann K, Hatz F, Sonnet S, Kully C, Gasser T, Sauter G, Mihatsch MJ, Moch H. VHL mutations and their correlation with tumour cell proliferation, microvessel density, and patient prognosis in clear cell renal cell carcinoma. J Pathol. 2002; 196:186-93.

30. Smits KM, Schouten LJ, van Dijk BA, Hulsbergen-van de Kaa CA, Wouters KA, Oosterwijk E, van Engeland M, van den Brandt PA. Genetic and epigenetic alterations in the von hippel-lindau gene: the influence on renal cancer prognosis. Clin Cancer Res. 2008; 14:782-7.

31. Gossage L, Murtaza M, Slatter AF, Lichtenstein CP, Warren A, Haynes B, Marass F, Roberts I, Shanahan SJ, Claas A, Dunham A, May AP, Rosenfeld N, et al. Clinical and pathological impact of VHL, PBRM1, BAP1, SETD2,
KDM6A, and JARID1c in clear cell renal cell carcinoma. Genes Chromosomes Cancer. 2014; 53:38-51.

32. Young AC, Craven RA, Cohen D, Taylor C, Booth C, Harnden P, Cairns DA, Astuti D, Gregory W, Maher ER, Knowles MA, Joyce A, Selby PJ, et al. Analysis of VHL Gene Alterations and their Relationship to Clinical Parameters in Sporadic Conventional Renal Cell Carcinoma. Clin Cancer Res. 2009; 15:7582-92.

33. Fernandez-Pello S, Hofmann F, Tahbaz R, Marconi L, Lam TB, Albiges L, Bensalah K, Canfield SE, Dabestani S, Giles RH, Hora M, Kuczyk MA, Merseburger AS, et al. A Systematic Review and Meta-analysis Comparing the Effectiveness and Adverse Effects of Different Systemic Treatments for Non-clear Cell Renal Cell Carcinoma. Eur Urol. 2017; 71:426-36.

34. He W, Tan R, Dai C, Li Y, Wang D, Hao S, Kahn M, Liu Y. Plasminogen activator inhibitor-1 is a transcriptional target of the canonical pathway of $\mathrm{Wnt} /$ beta-catenin signaling. J Biol Chem. 2010; 285:24665-75.

35. Chowdhury S, Matrana MR, Tsang C, Atkinson B, Choueiri TK, Tannir NM. Systemic therapy for metastatic nonclear-cell renal cell carcinoma: recent progress and future directions. Hematol Oncol Clin North Am. 2011; 25:853-69.

36. Brookman-May SD, May M, Wolff I, Zigeuner R, Hutterer GC, Cindolo L, Schips L, De Cobelli O, Rocco B, De Nunzio C, Tubaro A, Coman I, Truss M, et al. Evaluation of the prognostic significance of perirenal fat invasion and tumor size in patients with pT1-pT3a localized renal cell carcinoma in a comprehensive multicenter study of the CORONA project. Can we improve prognostic discrimination for patients with stage pT3a tumors? Eur Urol. 2015; 67:943-51.

37. Lam JS, Klatte T, Patard JJ, Goel RH, Guille F, Lobel B, Abbou CC, De La Taille A, Tostain J, Cindolo L, Altieri V, Ficarra V, Artibani W, et al. Prognostic relevance of tumour size in T3a renal cell carcinoma: a multicentre experience. Eur Urol. 2007; 52:155-62.

38. Svenson U, Ljungberg B, Roos G. Telomere length in peripheral blood predicts survival in clear cell renal cell carcinoma. Cancer Res. 2009; 69:2896-901.

39. Motzer RJ, Agarwal N, Beard C, Bolger GB, Boston B, Carducci MA, Choueiri TK, Figlin RA, Fishman M, Hancock SL, Hudes GR, Jonasch E, Kessinger A, et al. NCCN clinical practice guidelines in oncology: kidney cancer. J Natl Compr Canc Netw. 2009; 7:618-30.

40. Fuhrman SA, Lasky LC, Limas C. Prognostic significance of morphologic parameters in renal cell carcinoma. Am J Surg Pathol. 1982; 6:655-63.

41. Sorrentino A, Thakur N, Grimsby S, Marcusson A, von Bulow V, Schuster N, Zhang S, Heldin CH, Landstrom M. The type I TGF-beta receptor engages TRAF6 to activate TAK1 in a receptor kinase-independent manner. Nat Cell Biol. 2008; 10:1199-207. 